\title{
A Comparative Study of the Alienation Theory of Marx and that of Marcuse
}

\author{
Ren Qiaohua \\ School of Marxism, Shenyang Jianzhu University \\ Shenyang, China, 110168 \\ Tony805@163.com
}

\author{
Lu Qiuye* \\ School of Marxism, Shenyang Jianzhu University \\ Shenyang, China, 110168 \\ 1257165739@qq.com
}

\begin{abstract}
Due to the different historical background, there are many differences between the theory of alienation of Marx and that of Marcuse. From the perspectives of human alienation theory, alienation theory of science and technology as well as human liberation theory, the paper compares the theory of alienation of Marx with that of Marcuse, and indicates that as the phenomenon of alienation always exists in the process of societal and historical development, the relative theoretical approaches can be practically transformed into counterparts of the governmental policy making and implementation, in terms of understanding alienation in different context.
\end{abstract}

Keywords-Marx; Marcuse; Alienation Theory; Capitalism

\section{INTRODUCTION}

According to the living reality of people in capitalist society in the 19th century, Marx suggests from the Economic and Philosophical Manuscripts in 1844 that there are unfair conditions in the capitalist society in light of historical materialism. From the perspective of critique of capitalist society essence, he proposed that humankind should eventually be liberated only through the elimination of private ownership and violent revolution. Since the 20th century, under the new historical conditions, Marcuse inherited from the alienated thinking mainly in the Frankfurt School of "Floyd Marxism". In the face of the new industrial society, from the perspective of human psychology and humanity, Marcuse introduced the theory of consumer alienation and totalitarian social criticism from his monograph, entitled by One Dimensional Man, aimed at the liberation of all human beings on the basis of eros desire and general revolution. By comparing the theory of alienation between Marx and Marcuse, it will be helpful to recognize the new changes that have taken place in the process of the development of capitalist society, to clarify the theoretical differences between Marx and Marcuse, and to understand Marxism. It is also of certain theoretical and practical significance to conduct comprehensively deepening reform.

\section{THE COMPARISON FROM ALIENATION THEORY OF PEOPLE}

\section{A. The Theory of Labor Alienation of Marx}

In Manuscripts of Economics and Philosophy of 1844, Marx revealed the status quo of the entire capitalist society and the existence of capitalist social workers, exploring the nature and origin of private property, analyzing the relationship between the rulers and the ruled, proving the historical trend of the inevitable demise of the private ownership of the bourgeoisie. Marx pointed out that labor is seen as a means of human existence, whereas the laborer's objects of labor and the products of labor he produced are not owned by the laborers but owned by the capitalists, under the premise of private ownership of the means of production. The product which produced by workers became the alien force of oppressing workers. Labor of workers is alienated as a tool to rule people.

Therefore, Marx elaborates the four provisions that labor alienation ultimately is human alienation in Manuscripts of Economics and Philosophy of 1844:

\section{1) Alienation between laborers and labor products}

It can be seen from this that the laborer and the product of labor are viewed as alienated relations. Under the conditions of the capitalist private ownership, the laborers' products produced by their own diligent sweat should belong to themselves and be controlled by the laborers themselves [1]. However, The fruits of their labor are entirely owned by the capitalists. Workers not only cannot take control in these labor products, whereas these working products, in return, become the forces that dominate the workers. The more workers produce, the greater the power of dominance will be.

\section{2) Alienation between laborers and labor}

This alienation exists in the labor and producing process. Human own kind's essence is labor, and it is taken for granted that laborers in the labor process should be free, unrestrained and get paid. However, under the conditions of private ownership of capitalism, laborers do not voluntarily exert their own power to carry out labor but are exploited by capitalists to engage in productive activities forcibly. "The laborer is not affirming himself but denying himself; he is not happy; his body is devastated and his heart is tormented. His labor is not voluntary but enforced."[2] Accordingly, it seems that this kind 
of labor has become a kind of alienated labor and has broken away from the laborers themselves.

\section{3) Alienation between human own kind's essence and} human

Human own kind's essence is identified by the practice to change the world. It is called as subjective initiative and selfcreative. Due to the alienation of laborers and labor, laborers' labor is seen as the only way to maintain the survival of laborers in the sense that human beings will be treated as equal as working animals. In order to maintain their physical existence, the constantly aimless working makes such workers lack the self-creativity and subjective initiative. In this case, human are not human, as they are at odd with the nature of mankind. Alienated labor has changed human own kind's essence and let the alienation occurred between human own kind's essence and human being.

\section{4) Alienation between human and human}

The alienation between human being is often viewed as the alienation of human social relations. In terms of alienation, the former three kinds of relationships are related to the alienation between human being. In capitalist society, the alienation between laborers and the labor products, the labor process and the human own kind's essence of nature, will eventually lead to the alienation between the laborer and the actual owner of the labor product, namely, the relationship between laborer and capitalist is alienated. "Alienation of labor leads to the separation of human from its essence, the loss of human's value, the antagonism of people with their own, and the contradiction of human and human. The whole society is like a prison, and every man is the maker of this prison."'[3]

\section{B. Marcuse's Theory of Consumption Alienation}

Marcuse insisted that consumption should be regarded as a way of living for people. However, driven by the rapid development of science and technology, the productive forces in capitalist society are highly developed and their producing efficiency is unprecedentedly increased. In terms of living standards, not only are capitalists living a prosperous life, but also ordinary people can be satisfied at the material level. However, the capitalists still aim to exploit the surplus value produced by laborers. The laborers are still devastated in body and mind. The laborers can only seek for freedom and happiness through consumption. "People seem to be living for goods. Cars, high-definition fax machines, split-level family home and kitchen appliances become the souls of people.'[4]
In addition, for the production, reproduction and expanded reproduction, the capitalists make use of the advertising media to create false needs and to promote hedonistic lifestyles, which confuses people to buy goods from capitalists. People regard these false needs as a real need. Over time, governor generally controls people's awareness by consumption. Thereby, people's consumption behavior has been changed in the way that people do not go to consume for living, but live for consumption. In this sense, the relationship between people and product has been completely reversed. People's inclination to objects make them lose the subjective personality. "If the worker and his boss enjoy the same television program and roam the same amusement spot, if the typist dress as beautiful as her employer's daughters, and if the blacks also own the Cadillac Limousine, if they read the same newspaper. Similarity does not indicate the disappearance of classes, but rather indicates to what extent individuals under existing regimes share the need and satisfaction of maintaining such institutions."[4]Therefore, Marcuse believes that the nature of human beings is eros, and the false need is imposed by society. Although this imposing false need makes people feel satisfied at the material level, people ultimately is dominated by the products. Under the influence of this mechanism, people all seem to share the same benefits of mechanism. People seem happy, but in fact still depressive that they have completely lost their sense of social criticism in the name of freedom and equality [5].

Through the analysis of Marx's and Marcuse's theory of alienation, we can see that Marx's human alienation theory is based on the theory of alienation of labor. In the Manuscripts of Economics and Philosophy of 1844, Marx analyzed that since the productivity is not well developed, there is still have an exploitation relationship between capitalist and laborers. The productive materials are occupied by the capitalists for free, and capitalists gain high profits by exploiting the surplus value of laborers; Marcuse's alienation theory is based on the theory of consumption alienation. According to Marcuse, under the new historical conditions of a highly developed modern industrial society, the development of science and technology will enable workers to have rich consumption products. People are satisfied through consumption, but this is an unrealistic need. The more people buy, the deeper they fall into. People's spirit become depressed and vacant. This condition is called a kind of alienated consumption relationship [4]. Marcuse's theory of consumption alienation is taken for a kind of theoretical innovation that under the social and historical conditions Marx did not appear at that time. However, Marcuse weakened this exploitation relationship between capitalists and laborers. He ignored the fact that laborers still did not possess the means of production. This is a retrogressive performance relative to Marx's labor alienation theory. 


\section{THE COMPARISON FROM ALIENATION THEORY OF SCIENCE AND TECHNOLOGY}

\section{A. The Theory of Alienation of Science and Technology of Marx}

Marx saw the important role of science and technology in capitalist society in the early period. According to Marx, science and technology itself is a kind of force that plays a revolutionary and proactive role in history. With the development of capitalism, science and technology have a great influence on production, life and social development and is more and more widely applied. Science and technology promote the improvement of production efficiency, people's quality of life as well as societal progress, but we cannot ignore the negative effects, that is, the phenomenon of alienation of science and technology. According to Marx, the root cause of the alienation of science and technology is not the science and technology itself, but the result of the application of science and technology by the rulers in capitalist society.

For one thing, in the handicraft industry, workers used tools to carry out their work. Workers used their own power and skills to manipulate tools. Tools became symbols of a worker's soul. In the modern era of mechanization, the tools were replaced by machines, in which workers moved around largescale machines. Technology replaced workers' labor through the medium of big machines, and forced workers to serve machines mechanically and become machines' accessory. Thereby, there was a situation that the machine is the owner and workers are slaves in the factory. Therefore, science and technology is an alien and dominant power for workers [6].

For another, in capitalist society, science, technology and large-scale machines are all owned by capitalists. In the course of their production, reproduction and expansion for reproduction, as a form of capital, science, technology and machinery will continue to squeeze workers' surplus labor. Workers in the production process is not regarded an autonomous laborer, but as a forced laborer. They are not affirming their own achievements but denying themselves. Workers' bodies and spirits are subjected to double torture. Science, technology and machines, as a capital, have achieved dominant position. Therefore, judging from the essence of capitalism, the alienation of science and technology can not disappear in capitalist society.

\section{B. The Theory of One Dimensional Man and One Dimensional Society of Marcuse}

The word "one-dimension" first appeared in the book OneDimensional Man by Marcuse. Marcuse states clearly in OneDimensional Man that normal people have two dimensions: the first one refers to accept, affirm and obey the social reality; the second one refers to criticize the social reality, deny or even surpass this dimension. As a result of the rapid development of science and technology, Marcuse suggests that capitalist society has continuously progressed, material consumption has been greatly enriched; people's quality of life has been continuously improved; capitalist society has gradually been controlled by the science and technology. As the subtitle of One-Dimensional Man: "A Study of the Ideology of
Developed Industrial Society" states that science and technology are not playing their own positive role in capitalist society but gradually ideologicalization [7]. Society has become a totalitarian society, this society suppressed people's thinking and made people lose their criticism and negative and became a one-dimensional man with only a submissive attitude.

First, science and technology control and depress human nature. When the working class consumes the same kind of product as the other classes, the working class will realize that it is not different from the other classes. People will feel blissful and comfortable, and will not consider criticizing and denying the society but surely submissive to this society. However, Marcuse maintains that this controllable choice is not a true freedom. People enjoy their rich material life while losing their freedom of choice. True freedom is viewed as spiritual freedom. The control and repression to human beings by capitalist society led to the formation of one-dimensional man [4].

Second, science and technology creates "false needs". Capitalist society use its developed technology to control over people's psychology through advanced media such as advertising and television media. The rulers use modern media to step up the propaganda of false goods, and further consolidate their ideology. Under these ideologies' inculcation, people have created false needs. "When a society seems to be more and more satisfied with individual needs according to its own way of organization, the basic critical functions of independent thinking, freedom of will and political opposition are gradually denied." [4]3-4When people feel their false needs are met, they are attached to this system, addicted to false happiness and become one-way people.

The developed industrial society where one dimensional people survived is one dimensional society. Marcuse claims that the modern developed industrial society has one dimensional nature. The main manifestation is that in the political field, the highly developed modern industry society let the rulers succeed in achieving the integration of political opposites. First of all, due to the advancement of science and technology and the improvement of productivity, the quality of life of the working class has continuously improved. The working class gradually meets the present conditions of the society and lose its own critical standpoint and revolutionary consciousness. Capitalist system assimilates the proletariat and forms a totalitarian society without criticism and resistance; Second, the moderate unity among the different factions within the capitalist countries as common interests means "a tendency toward significant or partial convergence of opposing positions in the political field" [8], which has allowed the rulers to achieve political opposition integration successfully. In view of life, the highly developed modern industrial society leads to the same way of life, that is, the phenomenon of consumer alienation as mentioned above. From the culture point of view, a highly developed modern industrial society leads to the unification of a high-level culture and a realistic culture. Marcuse advocates that a high-level culture is a kind of critical and transcendental culture that is alienated from the reality culture and expresses the ideal of people. Today, due to the development of science and technology, the high-level culture and the reality culture are integrated. The cultural center 
becomes a commercial center, a sales center or a government center. Culture has become a form of merchandise, losing its original critical and class nature. The high-level culture expressing the ideal does not exist a dimension of criticizing the current state of society. Only leave a one dimension identical with the reality, can make it assimilated and surmounted by reality [9].

Through the analysis of Marx and Marcuse's theories on the alienation of science and technology, it can be seen that Marx's theory of alienation of science and technology mainly shows that human being's mechanization and the domination of science and technology as a form of capital. Marx continues to criticize labor dialectically. However, under the new historical conditions, Marcuse's theory of alienation in science and technology that mainly proceeds from the alienation of science and technology is taken for ideology. On the basis of inheriting Marx's alienation theory, he elaborates that under the influence of science and technology, capitalism totalitarian society and human living in this society become onedimensional man and one dimensional society.

\section{THE COMPARISON OF A CHANNEL FOR LIBERATION OF MANKIND}

\section{A. The Theory of Violent Revolution of Marx}

After revealing the nature of capitalist society, Marx put forward the approach to eliminating alienation by eliminating private ownership and division of labor. In line with Marx, the main task of eliminating private ownership and division of labor can only be the working class. First, the working class is the most oppressed and the most exploited class. They do not possess the means of production. Only by liberating the working class can make the total private ownership disappeared and finally liberating all mankind. Second, the working class always stands on the front line of labor production and represents the developing direction of advanced social productive force and have inherent class superiority. The working class's direction of struggle is the direction for all mankind.[10] In line with of Communist Manifesto, Marx in his writings emphasized that the realization of communism is the only way to liberate all mankind and the whole society. In order to achieve communism, the working class must through violent revolutionary and political struggles to change the modes of production, liberate and develop productivity, eliminate the private ownership and division of labor. Only though these methods can realize the freedom and all-around development of mankind and liberate the whole society and all mankind, and ultimately eliminate alienation, realize communism fundamentally.

\section{B. The Theory of Revolution of Totality of Marx}

Based on his own understanding of human nature, Marcuse considered that human essence is eros in Eros and Civilization. Marcuse came up with a theory of eros liberation by emphasizing that progress of science and technology suppresses human eros. Hereby, achieving human liberation means that the eros must be first liberated. Marcuse believed that the original system is a system which represses human nature, so that we must overthrow it and rebuild a new social formation that do not have suppression and give play to human eros. Marcuse believed that ideological reconstruction of the capitalist system should be carried out through a "revolution of totality" rather than a violent revolution, accordingly, liberate human eros [5]. Of course, the main target of this totality of revolution differs from the counterparts of Marx's violent revolution, whose main target for revolution is not the working class. Marcuse did not finally address how to carry out the totality of revolution in capitalist society and how to truly realize the liberation of human being. In this sense, Marcuse's theory of "revolution of totality" is full of exaggerated and fantastic elements. Based on the alienation of mankind, Marx found out the essence of exploiting and oppressing the working class by capitalist society and put forward the method of launching violent revolution through the working class, eliminating private ownership and division of labor, so as to realize the liberation of human freedom and all-around development. Marcuse, from the point of view of liberating human eros, pointed out that the existing system of capitalism should be overthrown in a non-violent revolution of totality, but Marcuse failed to see the essence of capitalist society and the root reason of alienation of capitalist society. Marcuse expects to achieve liberation only through the psychological and spiritual dimensions without resorting to the political revolution and using material means to solve the problem of alienation. The theory of the revolution of totality can only be a kind of "utopia".

\section{CONCLUSION}

Based on the theory of human alienation, the theory of alienation of science and technology and the theory of human liberation, this paper compares the differences between Marx and Marcuse's theory of alienation. Although Marx and Marcuse lived in different times, comparing the differences between the two theories of alienation will enable us to further strengthen the dominant position of Marxism and to demonstrate the scientific and revolutionary nature of Marxism. However, it is undeniable that Marcuse's theory of alienation is reasonable to us in the process of modernization. A series of problems caused by the alienation of science and technology in the process of the development of the western capitalist countries enable us to avoid them better in the process of realizing modernization. In the course of realizing the "two centenary goals" of China, it is of significance to stress the role of science and technology, giving full play to the positive role of science and technology, vigorously constructing the socialist culture, strengthening national cultural confidence, resisting the ideology in the west. It is also of importance to adhering to the coordinated development of material civilization and spiritual 
civilization, adhering to the people-centered development concept.

\section{ACKNOWLEDGMENT}

This paper is sponsored by Projects of the National Social Science Foundation of China (15CZX014), "EEM Program's Theoretical Development and Methodological implications".

\section{REFERENCES}

[1] Karl Marx and Frederick Engels: Volume 42 [M]. Beijing: People's Publishing House, 2006:90.

[2] Karl Marx. Manuscripts of Economics and Philosophy of 1844 [M]. Beijing: People's Publishing House, 1979: 54.

[3] Wu Yongzhong. Alienation of Labor and Alienation of Technology.Theories of Human Alienation between Marx and Heidegger [J]. Journal of Hengyang Normal University, 2008(01):17-20. (In Chinese)

[4] Herbert Marcuse. One-dimensional man: Studies in the ideology of advanced industrial society [M]. Boston: Beacon Press, 1964: 9, 8, 8, 34.

[5] Herbert Marcuse. Eros and Civilization [M]. Boston: Beacon Press, 1955: 96,111.

[6] Yang Zhi. Selected Readings of On Capital (2nd ed) [M]. Beijing: China Renmin University Press, 2011:126. (In Chinese)

[7] Deng Wenfei, Tan Touhong. A Comparative Study of Ideological Theory between Marx and Marcuse [J]. Journal of Hunan First Normal University, 2008(01): 85-87. (In Chinese)

[8] Herbert Marcuse. Technology, War And Fascism [M]. New York: The Press of Routledge, 1998:18.

[9] Herbert Marcuse. Towards A Critical Theory of Society [M]. New York: The Press of Routledge, 1998:23.

[10] Wei Hongjuan. A Comparative Study of Social Critical Theory of Marx and Marcuse [D]. Hangzhou: Zhejiang Sci-Tech University, 2010. (In Chinese) 